\title{
Enrichment in Heavy Metal (HM) and Rare Earth Element (REE) in Fluvial Placer Deposits: Case Study of Zambesi River (Mozambique)
}

\author{
Emanuela Marin $^{1}$, Carmela Vaccaro ${ }^{1}$, Dario Di Giuseppe ${ }^{1}$, Monia Procesi ${ }^{2}$, Alessandra Sciarra ${ }^{2}$, \\ Francesco Zarlenga ${ }^{3}$ \\ ${ }^{1 *}$ Ferrara University, Department of Physic and Earth Science, Via Saragat 1, 44122 Ferrara (Italy) \\ ${ }^{2}$ INGV Istituto Nazionale di Geofisica e Vulcanologia, Via di Vigna Murata, 605, 00143 Roma (Italy) \\ ${ }^{3}$ ENEA, Italian National Agency for New Technologies, Energy and Sustainable Economic Development, Energy Technologies
}

Department, Technical-Strategical Support Unit; Casaccia Research Centre, Via Anguillarese 301, 00123, Santa Maria di Galeria, Roma (Italy)

\begin{abstract}
Mozambique has a huge mineral potential that is largely untapped. Tantalum-niobium, other rare metals, gold and semiprecious stones are abundant. Deposits of heavy mineral sands and a wide range of industrial minerals comprise a few of the mineral wealth in Mozambique that are under development. One of the most interesting zones of Mozambique is definitely the Zambezi River, where the placers deposits are rich in HM and REE. For this reason, ENEA in 2013 has performed an extensive multidisciplinary research along the Lower Zambezi, in cooperation with the Minas Rio Bravo Company (Mozambique). The aim of the research is to verify the REE and heavy metal abundances by measuring geochemical and mineralogical characteristics of the sediments from the bottom of the Zambezi, in the area between Tete and Tambara cities. The analyses were carried out at the Department of Physics and Earth Science of Ferrara University by X-ray fluorescence analysis, X-ray diffraction analysis and pycnometer method. The result of $X R D$ shows that the main minerals are quartz and feldspar. Unfortunately, the XRD peak of the main mineral phases covers up the others. However, chemical analyses reveal high presence of Iron and Titanium oxides and trace elements, as Cesium, Chromium and Lanthanum, suitable for industrial mining purposes. Furthermore, the data of density are comparable to the detecting phases found with XRD. The goal of the survey is to determinate the economic value of the Zambezi sediments for industrial minerals sector. Secondly, the results are important to improve the geochemical and mineralogical knowledge of this zone.
\end{abstract}

Keywords: Zambezi, REE, HM, sediments, mineral industries

\section{Introduction}

The use of new technology increased the demand of raw materials, such as Heavy Metals (HM) and Rare Earth Elements (REE). The REE materials are used in a wide range of technology applications, ranging from lasers to magnets and catalysts. The REE are each similar in crustal concentration to commonplace industrial metals such as chromium, nickel, copper, zinc, molybdenum, tin, tungsten, or lead. The REE are concentrated in Apatite and Zircons, especially in syenites and highly differentiated leucogranite. These rocks are particularly abundant in pre-Paleozoic and Paleozoic cratons [1], [2].

Although many countries, such as Brazil, China and Iran have important deposits of HM and REE, but they may partially satisfy technology market demand. The scenario of the information revolution indicates the enormous potential of these mining activities. At present, extraction possibility is decreasing and it is important to find new exploitable zones. For this reasons mineral industries prefer to invest in exploration license before the mining activity [3].

Secondly, developing countries are interesting in cooperation with mineral industries to develop their economies. In more case in developing countries agricultural is the first economy activity but it is not enough to grow economically. The mineral exportation could be a good answer but with new extraction system in an ecological safety point of view [4], [5].

Mozambique has a large and diverse mineral resource potential and is one of the most important exporting nation of raw materials, in particular Coal, Aluminum and Gold. Despite this, Mozambique is a poor Nation and the country's economy and social welfare, amounting to only $1.8 \%$ of GDP in 2006 [6]. Recently Mozambique Governments wrote the Poverty Reduction Strategy Paper 2006-2009 (PRSP) with the aim to contributing to economic development. One of the point of PRSP is the engagement of foreign investments, as international industrial mining [7].

In 2013 the Minas Rio Bravo Lda., a Mozambican mining industry, obtained licenses for the extraction of sand from the river Zambezi. ENEA (National Agency for New Technologies, Energy and Sustainable Economic Development) in cooperation with Minas Rio Bravo, performed an extensive multidisciplinary research along the Lower Zambezi. In this paper, we introduce the results of mineral and geochemistry analyses of the sediment samplers collected during the ENEA's survey [8].

The aim of the research is of commercial interest and the 


\section{International Journal of Science and Research (IJSR) \\ ISSN (Online): 2319-7064}

Index Copernicus Value (2013): 6.14 | Impact Factor (2015): 6.391

researchers decided to investigate the placer deposits of Zambezi, where the geomorphological feature and the fluvial dynamic of placers give a high enrichment in Fe-Ti minerals such as ilmenite and Ti-bearing magnetite. These fluvial sediments are also enriched in $\mathrm{Cr}, \mathrm{V}, \mathrm{Nb}$ and $\mathrm{REE}$. The placer are deposits due to the mechanical agent, as marine, aeolian or lacustre where mineral with high density and hardness, as HM, are in high concentration. Some placers contain more than one economic mineral, as the black sands that include Ti-minerals and Zircon, or REE and gold. In the sediments the cut off and the commercial value are positively influenced for the presence of ultramafic complexes in the Zambezi River basin, and for the river dynamics, characterized by placer [9]- [11].

This paper not include a map with the distribution of sampling points, due to commercial confidentiality. The area of interest is located between the Tete and Tambara cities, at south of Cahora Bassa Dam, in the Lower Zambezi. Despite the absence of a detailed map, the study is very important, because at present there is a lack of knowledge about the mineralogical and geochemical characteristics of the sediments. Specifically the scientific literature about the chemical features of the Zambesi river sediments is very poor and several zones of the it, such as our study area, are still in uncontamined conditions. For this reason, we think that the proposed study can have an important role both for mineral exploration and monitoring activity [5], [12] - [14].

\section{Study Area}

The Zambezi River Basin is the fourth-largest African river and the largest in the Southern African. It is long approximately $2600 \mathrm{~km}$, from Kalene Hills in Zambia to Mozambique, where flow into Pacific Ocean in a large delta. It extends in eight countries as Angola, Botswana, Malawi, Mozambique, Namibia, Tanzania, Zambia and Zimbabwe and, along the shore, there are approximately 30 million of persons. The main economic activity near the river are agriculture, fishing and the mining extraction, both in industrial and artisanal manner [7], [15]. Secondly, electricity production by hydro power- system is an important economic resource and along the Zambezi there are several great dams:

- The Kariba Dam, shared by Zambia and Zimbabwe, built in 1958 [16];

- The Kafue Reservoir and the Itezhi-Tezhi Reservoir, completed in 1971 and in 1977, in Zambia [17];

- The Cabora Bassa Reservoir in Mozambique, realized in 1974 [18].

The zambezian dams deeply changed the environment and the relationships between man and river, especially for the water and sediment rate. Thanks to the dams, uncertainty associated with water flow is reduce, in particular during the rainy season. The water management policies are facilitate, and it is very important in a country as Mozambique afflicted by the world climate changes. The water resource management and the impacts are highly investigate in literature, more than the alteration in sedimentation rate [15], [19] - [24]. Now the lower accumulation rate of riverine sediments increase the coastal erosion phenomena [25].

Zambezi is divided into three zones, each having a distinctive geomorphological unity. The first of these extends from the headwaters to Victoria Falls; the second from the Falls to the edge of the Mozambique coastal plain, which commences below Cahora Bassa Gorge; while the third comprises the stretch traversing the coastal plain [20]. The last zone, called Lower Zambezi, is the area of our research.

The Lower Zambezi Valley could be described as a complex physical system with several macro-scale river zones, from the Cabora Bassa Dam to the Indian Ocean. The sampling area is in Tete Province, in the section of Zambezi between the cities of Tete and Tambara [8]. In this area the Zambezi is an anastomosing river with multiple, interconnected, coexisting channel belts on alluvial plains [26]. Here the main tributaries are the river basins of Luia and Revuboe from north, Luenha/Mazowe from south, in addition to the inflow from Cabora Bassa (Fig. 1). The geology of tributary valleys determinate the sediments characteristics of the samplers.



Figure 1: The study area

The geology and tectonic development were attributed to three major lithospheric plates, called East, West and South Gondwana of the PanAfrican orogenic cycle. For this reason the geology of the area is very complicated, for the presence of several stratigraphic sequences and outcrops [27].

The main geological structure is the Tete suite, a GabbroAnorthosite Complex, a layered intrusive, composed predominantly of gabbro, with subordinate leucogabbro, norite and anorthosite and minor but widespread ultramafic rock types, mostly pyroxenite. The Tete Suite rocks are very dense and black, locally very coarse-grained and are composed predominantly of titano-magnetite and ilmenite that contain up to $0.66 \%$ of vanadium oxide [28], [29].

Also in Tete province there is the Chipera Complex, a gabbro anorthosite intrusion where the Chipera massif representing the western extremity of the Tete Suite. This unit is composed of old charnockites, granitoids and brown granites, consisting of enderbites, mangerites and leucocharnockites.

Moreover, close to the Cabora Dam there is the Atchiza 


\section{International Journal of Science and Research (IJSR) \\ ISSN (Online): 2319-7064}

Index Copernicus Value (2013): 6.14 | Impact Factor (2015): 6.391

Suite, a mafic and ultramafic intrusion, considered the continuation of the Great Dyke of Zimbawe. The Atchiza suite consists of three main types of rock that are ultramafic cumulates (dunite and pyroxenites), mafic cumulates (medium-grained cumulate gabbro) and coarse-grained gabbro (non-cumulate gabbro) [30]-[33].

Mafic and ultramafic rocks of considerable size have high economic value, because could hide important industrial minerals as HM and REE. Due to these geological characteristics, Tete Province is one of the most important mineral and quarry area of Mozambico. Especially near the city of Tete there are the biggest coal deposit of the Mozambique and several mines of titaniferous-vanadiferous magnetite. Another important site is the Mount Muambe, an important fluorite deposit with an increased amount of niobium and REE, included in monazite and in pyrochlore [34] - [36].

\section{Materials and Methods}

A total of 15 sediment samples were collected from depth of $10 \mathrm{~cm}$, from the bottom of Zambezi river, in the area between the cities of Tete an Tambara, in Tete Province, Mozambique. The collected samples are untreated sediments, which were manually sieved in traditional sieves (stainless steel sieve) and the particle size used in the studies do not extend over the $2 \mathrm{~mm}$ of diameter.

The shipping campaign on the Zambezi River has been carried out in March and April 2013 and the samples were analyzed, in the same year, at the Physics and Earth Science Department at University of Ferrara (Italy).

To eliminate igroscopic water, the samplers were dried in a stove at $60^{\circ} \mathrm{C}$ for 24 hours and successively powdered using an agata mortar. For chemical and mineral analyses it is used the powder, and for density analyses the untreated samplers.

The mineralogical analyses were carried out by XRPD Analyses with a Philips PW1860/00 difractometer, using graphite-filtered $\mathrm{CuK} \alpha$ radiation $(0.154 \mathrm{~nm})$. The diffraction patterns were collected in the $2 \Theta$ angular range $5-50^{\circ}$ with 5 s/step $\left(0.02^{\circ} 2 \Theta\right)$. The software Qualx 2.0 open source program it was used for the qualitative and semi quantitative mineral identification. Quantitative chemical analyses were accomplished by XRF (ARL ADVANT XP, Thermo Corporation, USA). Calibrations were obtained analyzing certified reference materials [37]. The samples density was determined by an Helium Pycnometer (Micromeritics Accupyc 1330 with a $1 \mathrm{~cm} 3$ measuring cup).

\section{Results}

The mineral analyses underlines the bimodal distribution of the sediments, with an enrichment in Quartz and Oxides. The sialic material is based of Quartz and Feldspar mineral (Albite and Anorthite). In the area of the diffractogram around 30 and $402 \Theta$ is possible to see several peaks related to the iron minerals, as Hematite, Magnetite and Pyrite. Despite so, the peaks of iron minerals are very low, just above the detection limit. From these results, we verified that the mineral analyses was not the appropriate method to evaluate the presence of industrial minerals in our samplers, in particular minerals link to REE compounds, as Monazite or Zircon.

The evaluation of major and trace element XRF analyses suggest a high percentage of $\mathrm{SiO}_{2}$, in according to the mineral analyses. In the samplers, there are important percentage of $\mathrm{TiO}_{2}$ and $\mathrm{Fe}_{2} \mathrm{O}_{3}$, link to iron minerals as Hematite, Titanite or Magnetite. In Tab. 1 the main significant major elements by XRF analyses.

Table 1: Major Elements by XRF Analyses

\begin{tabular}{|c|c|c|c|c|c|}
\hline & $\mathbf{S i O}_{\mathbf{2}} \mathbf{\%}$ & $\mathbf{T i O}_{\mathbf{2}} \mathbf{\%}$ & $\mathbf{A L}_{\mathbf{2}} \mathbf{O}_{\mathbf{3}} \mathbf{\%}$ & $\mathbf{F e}_{\mathbf{2}} \mathbf{O}_{\mathbf{3}} \mathbf{\%}$ & $\mathbf{C a O \%}$ \\
\hline $\mathbf{C 1}$ & 72,8 & 3,2 & 6,2 & 12,2 & 1,4 \\
\hline C2 & 75,1 & 2,2 & 7,7 & 8,2 & 1,6 \\
\hline C3 & 79,4 & 1,4 & 6,8 & 5,9 & 1,5 \\
\hline C4 & 73,2 & 2,6 & 8,3 & 9,0 & 1,8 \\
\hline C5 & 79,6 & 1,5 & 6,4 & 7,1 & 1,4 \\
\hline C6 & 61,7 & 5,3 & 6,4 & 21,3 & 2,1 \\
\hline C7 & 59,1 & 5,4 & 7,4 & 21,8 & 2,5 \\
\hline C8 & 68,4 & 3,1 & 7,0 & 15,3 & 2,2 \\
\hline C9 & 85,3 & 1,4 & 5,9 & 1,5 & 2,0 \\
\hline C10 & 68,7 & 3,7 & 7,2 & 14,1 & 2,1 \\
\hline C11 & 79,5 & 1,7 & 6,9 & 6,1 & 1,3 \\
\hline C12 & 54,4 & 6,8 & 9,4 & 23,2 & 1,4 \\
\hline C13 & 76,6 & 2,0 & 6,4 & 8,8 & 2,1 \\
\hline C14 & 83,8 & 0,6 & 6,7 & 3,3 & 1,0 \\
\hline C15 & 60,5 & 5,0 & 7,6 & 19,0 & 3,3 \\
\hline
\end{tabular}

For a better evaluation, we used a simply statistical method in order to explore the correlation between major and trace elements by a correlation matrix or scatterplots (Tab. 2). The correlation matrix has been focussed on the relationship between the major elements and the $\mathrm{HM}$ as $\mathrm{Ni}, \mathrm{Pb}$ and $\mathrm{Zn}$, and the REE as $\mathrm{Ce}, \mathrm{La}, \mathrm{Nb}$ and $\mathrm{Y}$. Thise correlation is relevant when the value is higher or equal than $\pm 0,7$.

The ferromagnesian elements (Fe, Ti, Ni, $\mathrm{Pb}, \mathrm{Zn}$ ) and REE elements $(\mathrm{Ce}, \mathrm{La}, \mathrm{Nb}, \mathrm{Y})$ have negative correlations with $\mathrm{Si}$. Instead, the HM and REE elements have positive correlation with $\mathrm{Fe}$ and $\mathrm{Ti}$. This analysis suggest that the minerals composed of Iron and Titanium Oxides are reach in HM and REE. These results thus need to be interpreted with caution because the data not exclude the increase of HM and REE due to the mechanical concentration and not for a mineralogical contribution. Notwithstanding the lack of agreement, we believe our findings suggest that the placer sediments are suitable for mineral industries because there is a high percentage of ferromagnesian elements and REE. 


\section{International Journal of Science and Research (IJSR) \\ ISSN (Online): 2319-7064 \\ Index Copernicus Value (2013): 6.14 | Impact Factor (2015): 6.391}

Table 2: Correlation matrix

\begin{tabular}{|c|c|c|c|c|c|c|c|c|c|c|c|c|}
\hline & $\mathbf{S i}$ & $\mathbf{T i}$ & $\mathbf{A l}$ & $\mathbf{F e}$ & $\mathbf{C a}$ & $\mathbf{C e}$ & $\mathbf{L a}$ & $\mathbf{N b}$ & $\mathbf{Y}$ & $\mathbf{N i}$ & $\mathbf{P b}$ & $\mathbf{Z n}$ \\
\hline $\mathbf{S i}$ & $\mathbf{1}$ & & & & & & & & & & & \\
\hline $\mathbf{T i}$ & $\mathbf{- 1}$ & $\mathbf{1}$ & & & & & & & & & & \\
\hline $\mathbf{A l}$ & $-0,6$ & 0,6 & $\mathbf{1}$ & & & & & & & & & \\
\hline $\mathbf{F e}$ & $\mathbf{- 1}$ & $\mathbf{1}$ & 0,5 & $\mathbf{1}$ & & & & & & & & \\
\hline $\mathbf{C a}$ & $-0,5$ & 0,5 & 0,1 & 0,5 & $\mathbf{1}$ & & & & & & & \\
\hline $\mathbf{C e}$ & $\mathbf{- 0 , 8}$ & $\mathbf{0 , 9}$ & 0,6 & $\mathbf{0 , 8}$ & 0,3 & $\mathbf{1}$ & & & & & & \\
\hline $\mathbf{L a}$ & $\mathbf{- 0 , 8}$ & $\mathbf{0 , 9}$ & 0,6 & $\mathbf{0 , 8}$ & 0,3 & $\mathbf{1}$ & $\mathbf{1}$ & & & & & \\
\hline $\mathbf{N b}$ & $\mathbf{- 0 , 8}$ & $\mathbf{0 , 8}$ & $\mathbf{0 , 7}$ & $\mathbf{0 , 7}$ & 0,2 & $\mathbf{0 , 9}$ & $\mathbf{0 , 9}$ & $\mathbf{1}$ & & & & \\
\hline $\mathbf{Y}$ & $\mathbf{- 0 , 8}$ & $\mathbf{0 , 8}$ & 0,5 & $\mathbf{0 , 8}$ & $\mathbf{0 , 8}$ & $\mathbf{0 , 8}$ & $\mathbf{0 , 8}$ & $\mathbf{0 , 7}$ & $\mathbf{1}$ & & & \\
\hline $\mathbf{N i}$ & $\mathbf{- 0 , 7}$ & 0,6 & 0,1 & $\mathbf{0 , 7}$ & $\mathbf{0 , 9}$ & 0,3 & 0,3 & 0,2 & 0,6 & $\mathbf{1}$ & & \\
\hline $\mathbf{P b}$ & $\mathbf{- 0 , 8}$ & $\mathbf{0 , 8}$ & $\mathbf{0 , 8}$ & $\mathbf{0 , 7}$ & 0,1 & $\mathbf{0 , 8}$ & $\mathbf{0 , 9}$ & $\mathbf{0 , 8}$ & 0,6 & 0,2 & $\mathbf{1}$ & \\
\hline $\mathbf{Z n}$ & $\mathbf{- 1}$ & $\mathbf{1}$ & 0,5 & $\mathbf{1}$ & 0,6 & $\mathbf{0 , 8}$ & $\mathbf{0 , 9}$ & $\mathbf{0 , 8}$ & $\mathbf{0 , 9}$ & $\mathbf{0 , 7}$ & $\mathbf{0 , 7}$ & $\mathbf{1}$ \\
\hline
\end{tabular}

The Tete Complex is the main geological structure near the Tete and Tambara cities. To evaluate the relationship between Tete Complex and Zambezi sediments, we compared the data quoted by Barr and Brown (1987), where there are the major elements of mother rocks as Gabbro, Norite and Pyroxenite. This relation can be determined using the $\mathrm{CaO}-\mathrm{Al}_{2} \mathrm{O}_{3}-\mathrm{SiO}_{2}$ triangular diagram (Fig. 2).

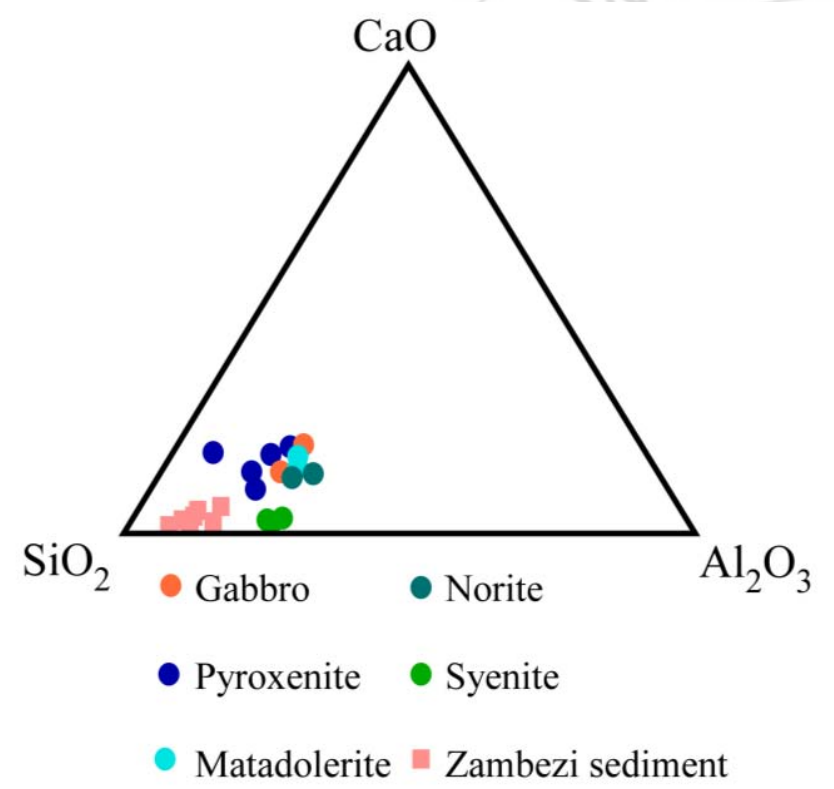

Figure 2: $\mathrm{CaO}-\mathrm{Al}_{2} \mathrm{O}_{3}-\mathrm{SiO}_{2}$ triangular diagram

The diagram shows that the Zambezi sediments are very close to the mother rocks of Tete Complex. The increase in $\mathrm{SiO}_{2}$ and decrease in $\mathrm{CaO}$ is due to the weathering processes, characterized by the early $\mathrm{Na}$ and $\mathrm{Ca}$ removal stage, the intermediate $\mathrm{K}$ removal stage and the more advanced $\mathrm{Si}$ removal stage [38, 39]. Therefore the main component of Zambezi sediments are Quartz and chemically unstable grains (plagioclase and volcanic rock fragments) that derived especially from Tete Complex. The weathering mechanism degrade unstable grains in clay minerals and in the survey area there are low deteriorate sediments. The data confirm that the sediments are comparable to Tete Complex rocks, where operate important mineral industries. The density data are integrated with all the results from the previous analyses (Fig. 3). The average density is very close to the main mineral phases as Quartz 2,65 g/cm3, Anorthite $2,76 \mathrm{~g} / \mathrm{cm}^{3}$ and Albite 2,63 g/cm3 [40]. Where the density is higher, the presence of iron minerals are important (Hematite $5,25 \mathrm{~g} / \mathrm{cm}^{3}$ and Pyrite $\left.5,02 \mathrm{~g} / \mathrm{cm}^{3}\right)$. This is important, because the specific weight of the sand is a great and fast preliminary method to separate sediments rich in Iron minerals and sediments with high presence of Quartz.



Figure 3: The density histogram

\section{Discussion}

One of the main goals of these experiments was to understand the suitability of the sediments for mineral industrial purposes. The sediments came from the Zambezi River, near the cities of Tete and Tambara. The sediments were collected in 2013 from the bottom of the river, in the area corresponding placer accumulation. For the evaluation of the sediment characteristics, it was used the XRD analyses, the XRF analyses and density analyses using a pycnometer. The results both negate and support some of the hypotheses.

The XRD diffractogram showed unsuitable response, because the high peaks of Quartz covered the other. This result indicates that the main mineral in the sediment is Quartz. Nevertheless, in the diffractogram is possible to discriminate the presence of Feldspars and a little quantities of Iron minerals, as Hematite and Pyrite.

Thanks to geochemical data, it is possible to understand the relationships between the major elements and the HM and REE in trace. In the correlation matrix the HM and REE elements have positive correlation with $\mathrm{Fe}$ and $\mathrm{Ti}$. A reasonable explanation of the HM and REE enrichment is the natural concentration in the placer formation, because the minerals with high density are accumulated preferentially.

Density data are comparable with the mineral and geochemical results, because the average density $(2,8 \mathrm{~g} / \mathrm{cm} 3)$ is very close to the density of the main mineral individuated in the sediments, as Quartz and Feldspars. Where the value of density is high, Iron and Titanium Oxides increase.

For evaluate the correspondence of the sediments to the Tete Rocks geochemistry, further tests was carried out. The results demonstrate that the weathering state in the sediments is in an early phase. The sediments have a geochemistry very close to the Tete rocks, where there are several mineral mining. Quartz and chemically unstable grains (plagioclase and volcanic rock fragments) composed the sediments. 


\section{International Journal of Science and Research (IJSR) \\ ISSN (Online): 2319-7064}

Index Copernicus Value (2013): 6.14 | Impact Factor (2015): 6.391

The most remarkable result to emerge from the data is that the sediments of our survey are suitable for industries processes. It is crucial to note that several circumstances contribute to this situation:

- The HM and REE enrichment by sedimentation and density mechanism in placer area;

- A less deteriorate sediments, with more fragments of volcanic rocks;

- Low cost of local labor [7].

For this reasons we think it could be interesting to develop new mineral industries in the Zambezi River, in the survey area. In order to minimize the environmental impact, the future mining industries is important to delineate all activities, from the collection of the raw material to the processing and logistics procedures.

\section{Acknowledgment}

The authors are thankful to Minas Rio Bravo Lda, for providing us valuable data. We also thank the laboratory technicians Dr. Massimo Verde for the XRF analysis, Dr. Renzo Tassinari for XRD analysis and Dr. Umberto Tessari for density evaluation.

\section{References}

[1] G. B. Haxel, J. B. Hedrick, G. J. Orris, P. H. Stauffer, J. W. Hendley, "Rare earth elements: critical resources for high technology", USGS Numbered Series, 087-02, 2002.

[2] S. Massari, M. Ruberti, "Rare earth elements as critical raw materials: Focus on international markets and future strategies", Resources Policy, 38, (1), 36-43, 2013.

[3] G. Hilson, A. J. Basu, "Devising indicators of sustainable development for the mining and minerals industry: An analysis of critical background issues", International Journal of Sustainable Development \& World Ecology, 10, (4), 319-331, 2003.

[4] P. C. Crowson, A perspective on worldwide exploration for minerals, World Mineral Exploration: Trends and Economic Issues, Washington, DC, 1988.

[5] B. Kř́bek, B. De Vivo, T. Davies, "Special Issue: Impacts of mining and mineral processing on the environment and human health in Africa", Journal of Geochemical Exploration, 144, Part C, 387-390, 2014.

[6] Y. Pekkala, T. Kuivasari, R. Gonçalves, M. Deus, F. Chaúque, C. Almeida, "Review of industrial minerals in Mozambique" Geol. Surv. Finland, Spec. Pap, 48, 289306, 2008.

[7] S. Dondeyne, E. Ndunguru," Artisanal gold mining and rural development policies in Mozambique: Perspectives for the future", Futures, 62, Part A, 120-127, 2014.

[8] F. Pasanisi, C. Tebano, F. Zarlenga, "Indagine morfologica su un tratto del fiume Zambesi, nella Repubblica del Mozambico. Misure batimetriche ed analisi dei dati", 2015.

[9] H.G. Dill, "Grain morphology of heavy minerals from marine and continental placer deposits, with special reference to Fe-Ti oxides", Sedimentary Geology, 198, (1-2), 1-27, 2007.
[10]G. Els, P. Eriksson, "Placer formation and placer minerals", Ore Geology Reviews, 28, (4), 373-375, 2006.

[11]H. G. Dill, B. Weber, F. Melcher, W. Wiesner, F. Melcher, A. Müller, "Titaniferous heavy mineral aggregates as a tool in exploration for pegmatitic and aplitic rare-metal deposits (SE Germany)", Ore Geology Reviews, 57, 29-52, 2014.

[12] J. Plant, J. Baldock, H. Haslam, B. Smith, "The role of geochemistry in environmental and epidemiological studies in developing countries: a review", Geological Society, Special Publications, 113, 7-22, 1996.

[13]P. Ronco, G. Fasolato, M. Nones, G. Di Silvio, "Morphological effects of damming on lower Zambezi River", Geomorphology, 115, (1-2), 43-55, 2010.

[14] K. B. John, Ore forming potential of the Atchiza Suite and Sustainable management of mineral deposits in Mozambique: Petrology, geochemistry and sustainable management of mineral deposits", 2012.

[15] C. J. Vörösmarty, B. Moore III "Modeling basin-scale hydrology in support of physical climate and global biogeochemical studies: An example using the Zambezi River", Surveys in Geophysics, 12, (1-3), 271-311, 1991.

[16]D. M. Hughes, "Whites and water: How Euro-Africans made nature at Kariba dam", Journal of Southern African Studies, 32(4), 823-838, 2006.

[17] M. Mumba, J. R. Thompson, "Hydrological and ecological impacts of dams on the Kafue Flats floodplain system, southern Zambia", Physics and chemistry of the Earth, parts A/B/C, 30, (6), 442-447, 2005.

[18]A. Isaacman, C. Sneddon, "Toward a social and environmental history of the building of Cahora Bassa Dam", Journal of Southern African Studies, 26, (4), 597632, 2000

[19]P. Ronco, G. Fasolato, G. Di Silvio, "The Case of the Zambezi River in Mozambique: some investigations on solid transport phenomena downstream Cahora Bassa Dam", In Proceeding of International Conference on Fluvial Hydraulics, Riverflow, 1345-1354, 2006.

[20] A. E. Moore, F. P. Cotterill, M. P. Main, H. B. Williams, The Zambezi River, in Large rivers: geomorphology and management, Chichester, England, Hoboken, John Wiley, 2007.

[21]L. Beck, T. Bernauer, "How will combined changes in water demand and climate affect water availability in the Zambezi river basin?", Global Environmental Change, 21,(3), 1061-1072, 2011.

[22] T. Cohen Liechti, J. P. Matos, J.-L. Boillat, A. J. Schleiss, "Comparison and evaluation of satellite derived precipitation products for hydrological modeling of the Zambezi River Basin", Hydrology and Earth System Sciences, 16, (2), 489-500, 2012.

[23] H. Kling, P. Stanzel, M., Preishuber, "Impact modelling of water resources development and climate scenarios on Zambezi River discharge", Journal of Hydrology: Regional Studies, 1, 17-43, 2014.

[24] S. Fanaian, S. Graas, Y. Jiang, P. van der Zaag, “An ecological economic assessment of flow regimes in a hydropower dominated river basin: The case of the lower Zambezi River, Mozambique", Science of The Total Environment, 505, 464-473, 2015. 


\section{International Journal of Science and Research (IJSR) \\ ISSN (Online): 2319-7064}

Index Copernicus Value (2013): 6.14 | Impact Factor (2015): 6.391

[25]R. Beilfuss, C. Brown, “Assessing environmental flow requirements and trade-offs for the Lower Zambezi River and Delta, Mozambique", Intl. J. River Basin Management, 8, (2), 127-138, 2010.

[26] B. Makaske, "Anastomosing rivers: a review of their classification, origin and sedimentary products", EarthScience Reviews, 53, (3), 149-196, 2001.

[27]H. Schulz, A. Lückge, K. Emeis, A. Mackensen, "Variability of Holocene to Late Pleistocene Zambezi riverine sedimentation at the upper continental slope off Mozambique, $15^{\circ}-21^{\circ} \mathrm{S}$ ”, Marine Geology, 286, (1-4), 21-34, 2011.

[28] M. W. C. Barr, M. A. Brown, "Precambrian gabbroanorthosite complexes, Tete Province, Mozambique", Geological Journal, 22, (S2), 139-159, 1987.

[29]H. Mäkitie, M. I. Lehtonen, T. Manninen, J. M. Marques, G. Cune, H. Mavíe, "Petrography and geochemistry of granitoid rocks in the northern part of Tete Province, Mozambique", Geological Survey of Finland, Special Paper, 48, 167-189, 2008.

[30] A. M. A. Giacomo, "Petrochemistry, tectonic evolution and metasomatic mineralisations of Mozambique belt granulites from S Malawi and Tete (Mozambique)", Precambrian Research, 25, (1-3), 161-186, 1984.

[31] A. P. Westerhof, A. Tahon, T. Koistinen, T. Lehto, C. Åkerman, "Igneous and Tectonic Setting of the Allochthonous Tete Gabbro-Anorthosite Suite, Mozambique", GTK Consortium Geological Surveys in Mozambique 2002-2007, 48, 191-210, 2008a.

[32]A. P. Westerhof, M. I. Lehtonen, H. Mäkitie, T. Manninen, Y. Pekkala, B. Gustafsson, A. Tahon, "The Tete-Chipata Belt: A new multiple terrane element from western Mozambique and southern Zambia", Geological Survey of Finland Special Paper, 48, 145-166, 2008 b.

[33] D. L. Ibraimo, R. B. Larsen, "Geological setting, emplacement mechanism and igneous evolution of the Atchiza mafic-ultramafic layered suite in north-west Mozambique", Journal of African Earth Sciences, 111, 421-433, 2015.

[34] V. Cílek, J. Duda, "Industrial minerals of Mozambique”, Geological Survey Office, 1989.

[35] T. Lehto, R. Goncalves, "Mineral resources potential in Mozambique", Geological Survey of Finland, 48, 307321, 2008.

[36] U. S. Department of Interior, and U. S. Geological Survey, Minerals Yearbook 2008: Area Reports, International, Europe and Central Eurasia, Government Printing Office, 2011.

[37]D. Di Giuseppe, G. Bianchini, B. Faccini, M. Coltorti, "Combination of wavelength dispersive X-ray fluorescence analysis and multivariate statistic for alluvial soils classification: a case study from the Padanian Plain (Northern Italy)" X-Ray Spectrometry, 43, (3), 165-174, 2014.

[38]X. Xie, Y. Wang, A. Ellis, C. Liu, M. Duan, J. Li, "Impact of sedimentary provenance and weathering on arsenic distribution in aquifers of the Datong basin, China: Constraints from elemental geochemistry", Journal of Hydrology, 519, 3541-3549, 2014.

[39] C. M. Fedo, H. W. Nesbitt, G. M. Young, "Unraveling the effects of potassium metasomatism in sedimentary rocks and paleosols, with implications for paleoweathering conditions and provenance", Geology, 23, (10), 921-924, 1995.

[40]D.R. Lide, "RC Handbook of Chemistry and Physics. (84th ed.)", CRC Press, Bocca Raton, Florida, 2003. 